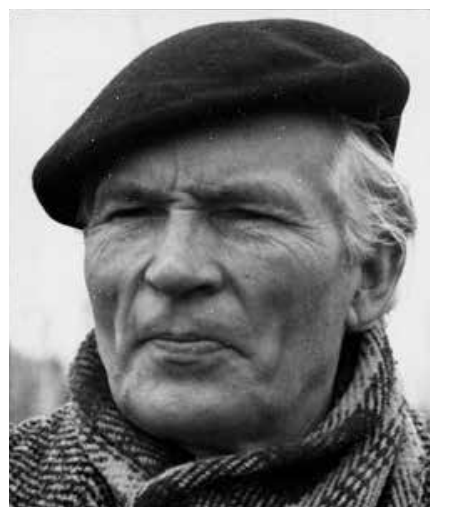

\title{
MENININKAS ZENONAS VARNAUSKAS
}

ZENONAS VARNAUSKAS (1923-2010) gimė Gelgaudiškyje, Šakių rajone. Vaikystėje su šeima gyveno Joniškio rajone, 1934-1937 m. mokẻsi Šiaulių gimnazijoje. Dar pradinėse klasėse buvo pastebėti jo gabumai dailei. Varnauskas, $1940 \mathrm{~m}$. baigęs vidurinę mokyklą, istojo ị Kauno taikomosios dailès institutą. Studijavo tekstilę ir grafiką. Varnauskui dėstė buvusios Kauno meno mokyklos pedagogai, garsūs menininkai Viktoras Petravičius, Liudas Truikys, Vytautas Kairiūkštis, Antanas Kučas ir kiti. 1947 m. Varnauskas baigè studijas igydamas pirmąji Lietuvoje profesionalaus dailininko-tekstilininko diplomą.

1947-2000 m. Varnauskas dirbo įvairiose Kauno meninio ugdymo įstaigose: Taikomosios ir dekoratyvinès dailès institute, ji panaikinus - Kauno taikomosios dailès vidurinėje mokykloje, Kauno Stepo Žuko taikomosios dailès technikume. 1958 m. Varnauskas pradèjo rūpintis aukštųjų dailès studijų Kaune atkūrimu. Po vienerių metu, 1959 m. rudenį, jis tapo faktiniu Lietuvos TSR Valstybinio dailès instituto Kauno vakarinio skyriaus vadovu (iki 1974 m.). Visą gyvenimą Varnauskas aktyviai dirbo pedagoginį darbą, dèstė tekstilès kompoziciją, piešimą ir tapybą Vilniaus dailès akademijos Kauno fakultete.

Kūrybinis dailininko gyvenimas truko beveik penkiasdešimt metų. Iki devinto dešimtmečio vidurio Varnauskas dirbo keliose srityse - kūrẻ meninę tekstilę, tapė peizažus, eskizavo iš natūros. Tekstilei būdingas ornamentiškumas, dekoratyvumas. Vèliau atsidavè vien tapymui ir grafikos eksperimentams, sukūrè autorinę grafikos kūrimo technologiją, kurioje svarbus vaidmuo tenka kopijavimo mašinai. Varnausko tapyboje ir grafikoje vyrauja dvi temos, sujungtos i ciklus Motina ir vaikas bei Nemuno krašto žmonès. Varnausko tekstilès, tapybos ir grafikos kūrinių yra pagrindinių Lietuvos dailès muziejų kolekcijose, nemaža dalis saugoma dailininko vardo fonde.

\section{Artist Zenonas Varnauskas}

ZENONAS VARNAUSKAS (1923-2010) was born in Gelgaudiškis, Šakiai district. During childhood he lived with his family in Joniškis district. In 1934-1937, he studied at Šiauliai Gymnasium. His talents for the arts became prominent in primary grades. After graduating from secondary school in 1940, Varnauskas enrolled 
to the Kaunas Institute of Applied Arts where he studied textiles and graphics. Zenonas Varnauskas was taught by famous artists of the former Kaunas School of Art: Viktoras Petravičius, Liudas Truikys, Vytautas Kairiūkštis, Antanas Kučas and others. In 1947 Varnauskas graduated and acquired the first diploma of a professional artist-textile artist in Lithuania.

In 1947-2000, Varnauskas worked in various Kaunas art education institutions: the Institute of Applied and Decorative Arts, after the closure of the former. at Kaunas Secondary School of Applied Arts, and at the Kaunas Stepas Žukas Technical School of Applied Arts. In 1958, Varnauskas started to take responsibility for the restoration of higher art studies in Kaunas. One year later, in the autumn of 1959 he became the actual head of the Kaunas Western Branch of the State Art Institute of the Lithuanian SSR (until 1974). Throughout his life, Varnauskas was actively involved in pedagogical work, teaching textile composition, drawing and painting at the Kaunas Branch of the Vilnius Academy of Arts.

The creative life of the artist lasted for almost fifty years. Until the middle of his 9th decade Varnauskas worked in several areas - creating artistic textiles, painting landscapes, and sketching from nature. His textiles are characterised by ornamentation and a high level of decorations. He later dedicated himself solely to painting and graphic experiments. He developed a graphics creation technology with the copying machine playing an important role. There are two dominant cyclic themes in the paintings and graphics of Varnauskas, the cycles "Mother and Child" and "People of the Nemunas Region". Many textile, painting and graphic works of Varnauskas are included in the collections of the major Lithuanian art museums. A large part of them are kept in the fund after the name of the artist.

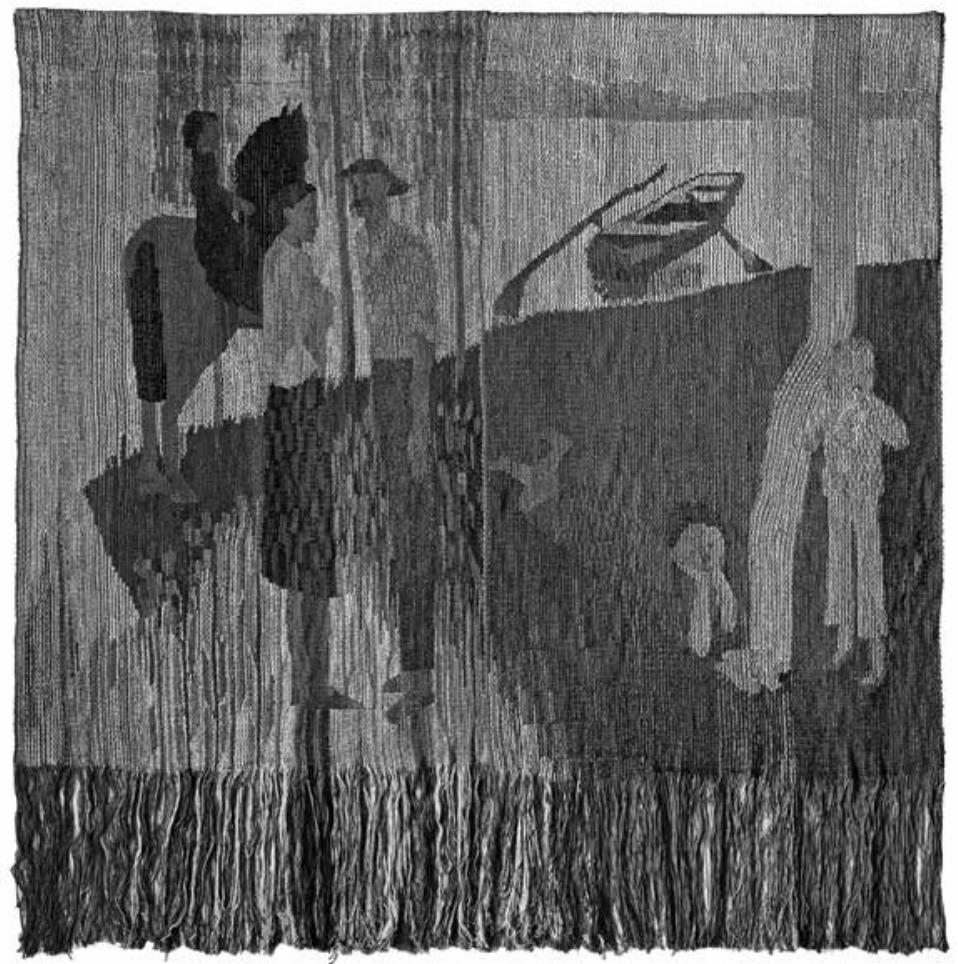

Zenonas VARNAUSKAS. Nemuno krašto žmonès. I-II. 1983. Gobelenas, špagatas, pusvilnè, medvilnè, I - 308 x $157 \mathrm{~cm}, \mathrm{II}-308 \times 158 \mathrm{~cm}$ Nacionalinis M. K. Čiurlionio dailès muziejus, I - Tt 11582, II - Tt 11583. Fotografija Audriaus Kapčiaus 


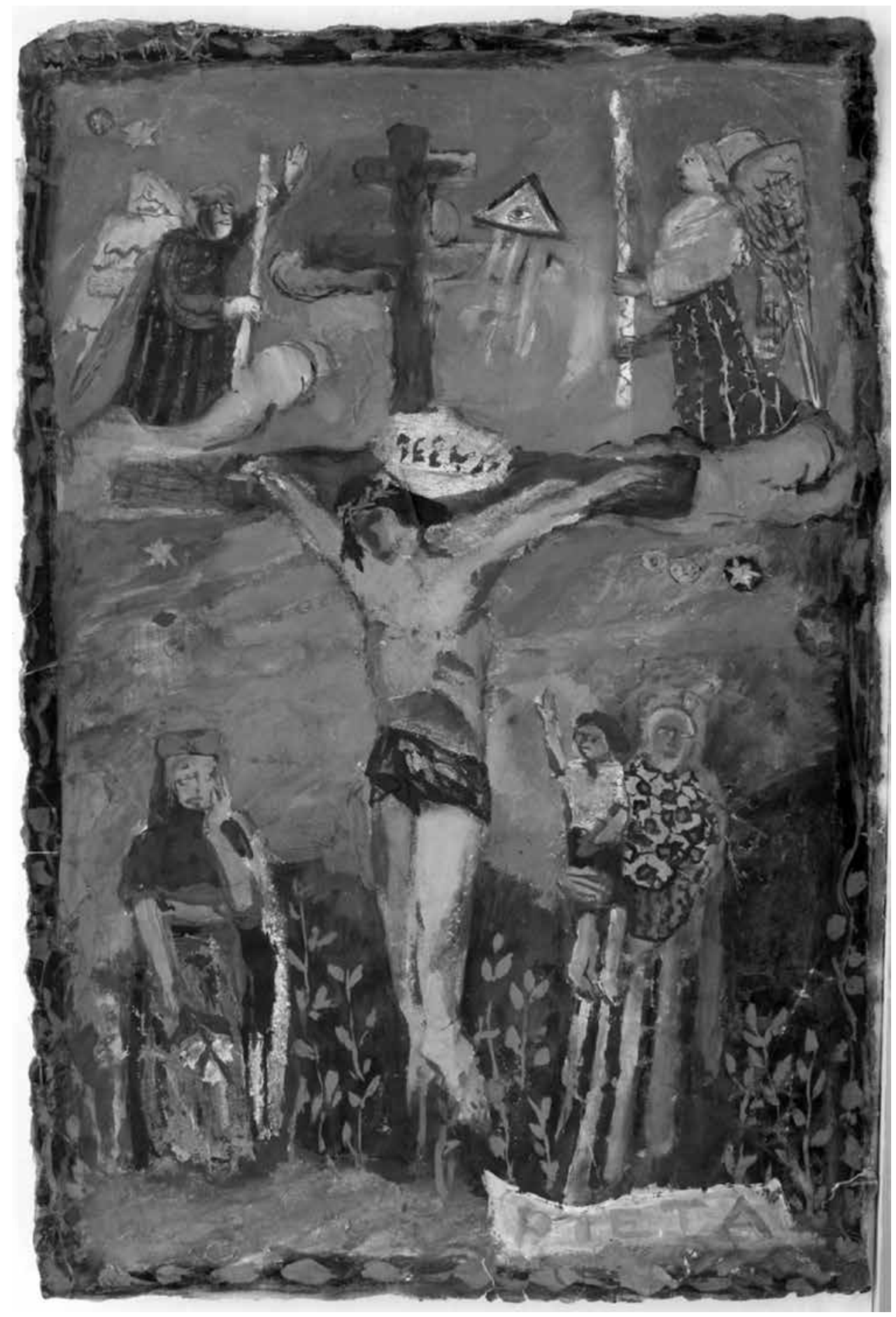

Zenonas VARNAUSKAS. Nukryžiuotasis (Pieta). 1941. Popierius, guašas, $68 \times 46,5 \mathrm{~cm}$

Zenono Varnausko fondas. Fotografija Rimvydo Varnausko 


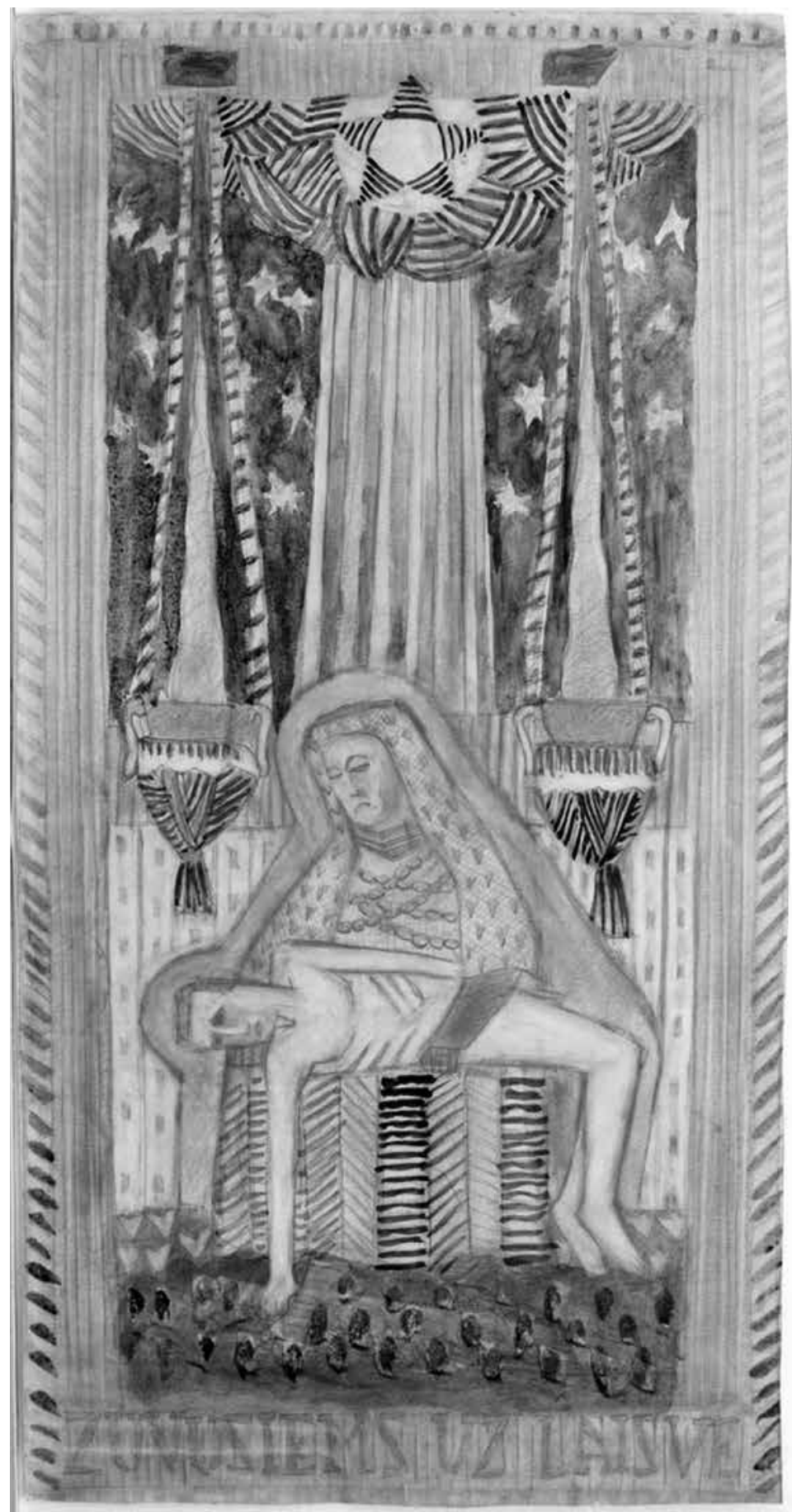

Zenonas VARNAUSKAS. Žuvusiems už laisvę (Pieta). Tekstilès projektas.

Apie 1942 m. Popierius, pieštukas, akvarelè, 71,5 × $37 \mathrm{~cm}$

Zenono Varnausko fondas. Fotografija Rimvydo Varnausko 


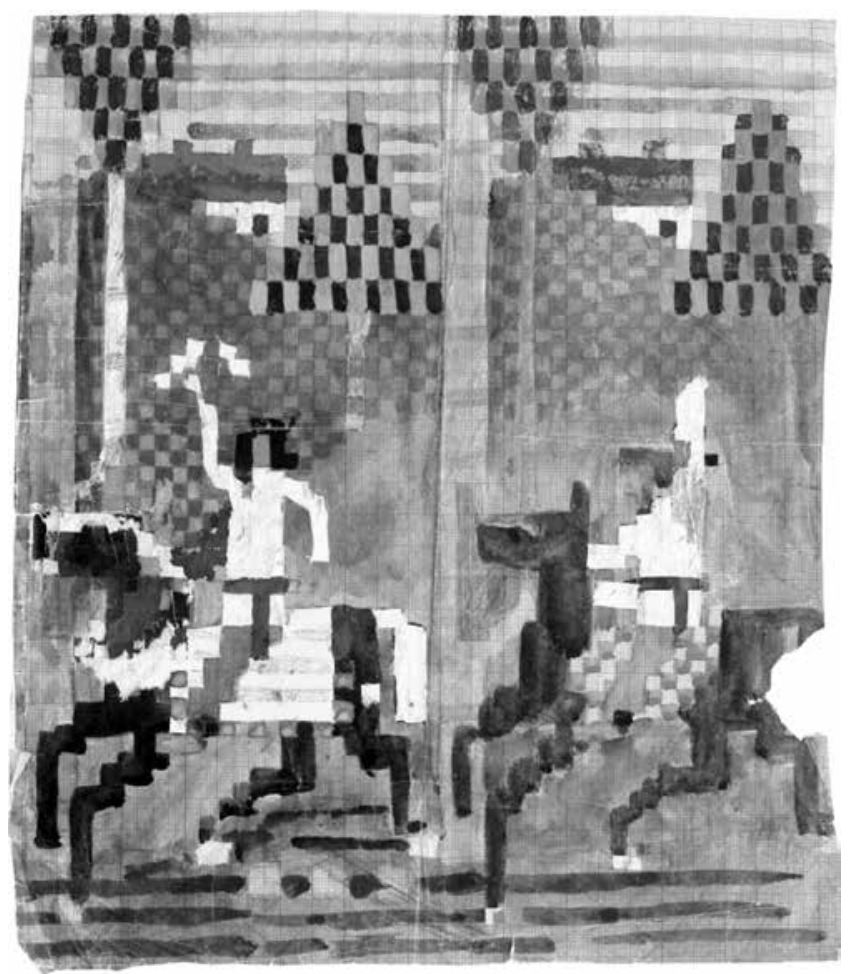

Zenonas VARNAUSKAS. Kai aš jojau. Eskizas I. 1959-1960.

Popierius, guašas, $30,5 \times 26,5 \mathrm{~cm}$. Zenono Varnausko fondas. Fotografija Rimvydo Varnausko

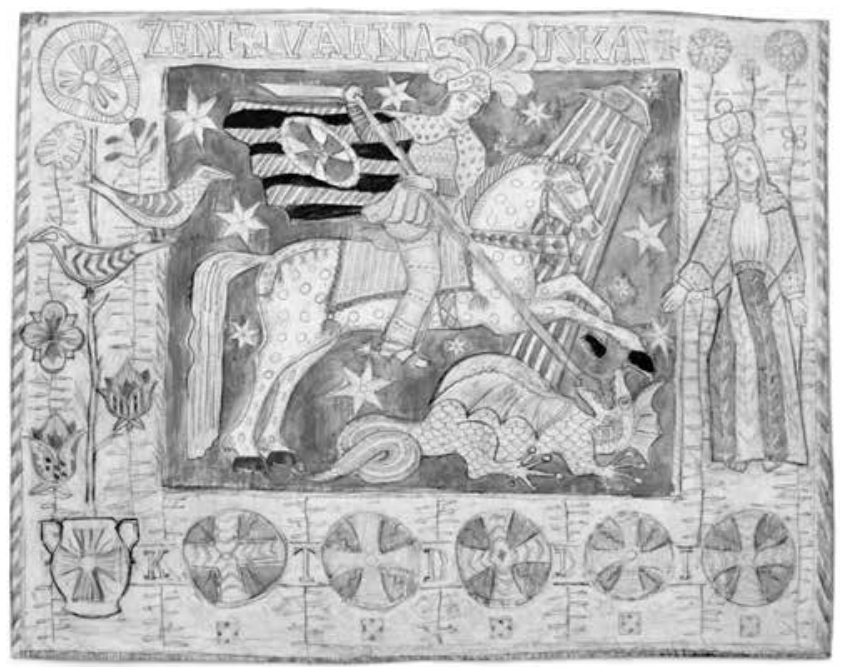

Zenonas VARNAUSKAS. Be pavadinimo (Kompozicija su šv. Jurgiu). Tekstilès projektas. Apie 1942. Popierius, tušas, guašas, 41,5 ×53 cm Zenono Varnausko fondas. Fotografija Rimvydo Varnausko 


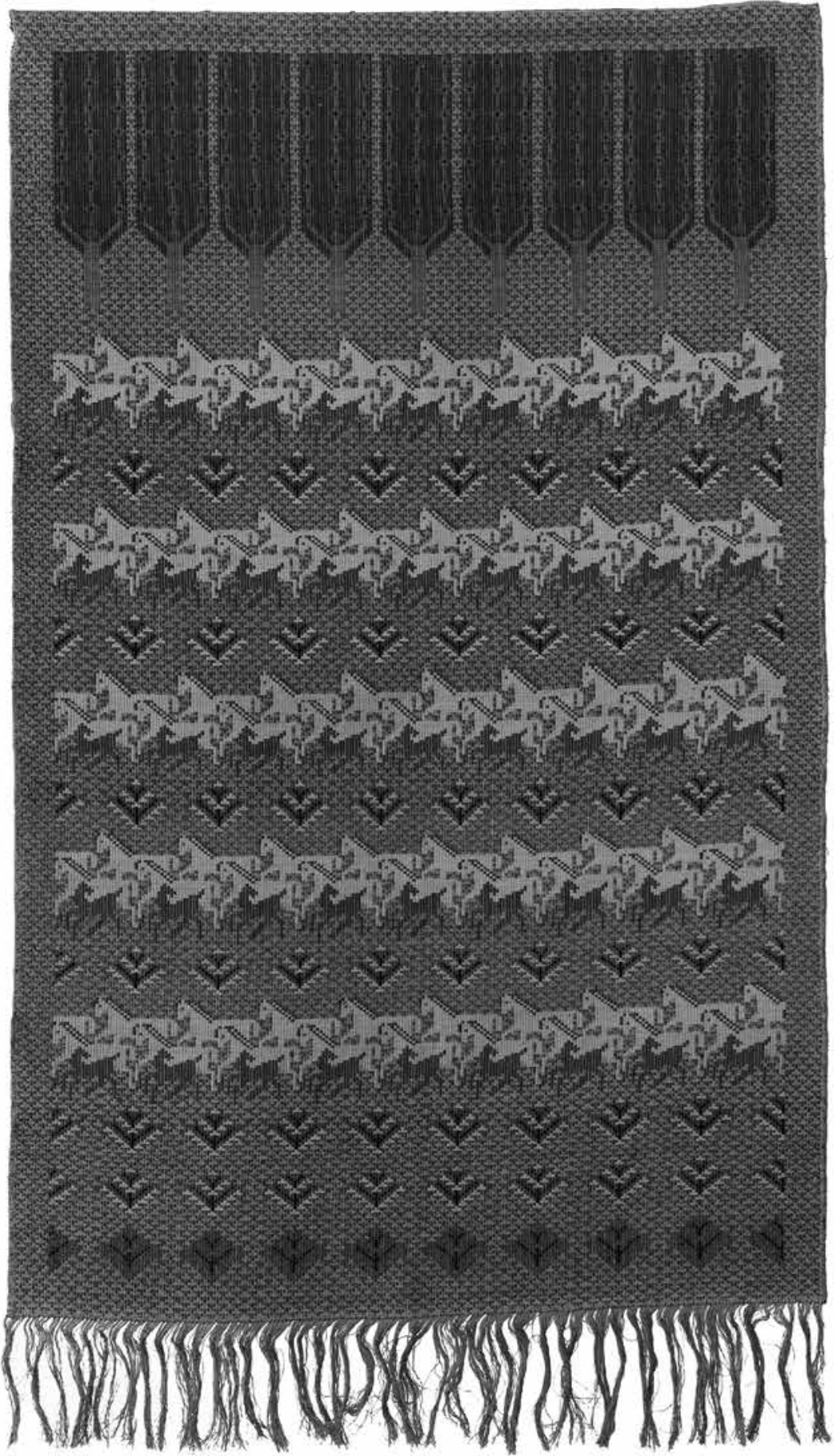

Zenonas VARNAUSKAS. Žirgynas. 1963. Austinis kilimas, linas, medvilnė, pusvilnè, $165 \times 101 \mathrm{~cm}$. Nacionalinis M. K. Čiurlionio dailès muziejus, Tt 5386 .

Fotografija Audriaus Kapčiaus 